Latchkeys, Liberty, and Liminality: Sarah Grand's "When the Door Opened

\title{
ANNE-MARIE BELLER
}

Sarah Grand is usually associated with didactic non-fiction, primarily her provocative 1894 article "New Aspects of the Woman Question", which is credited with having coined the term "New Woman"; or as the author of novels anchored in the realist mode such as The Heavenly Twins and The Beth Book. Yet Grand's short fiction offers a different perspective, often revealing her to be an innovative writer who plays with form and narrative in unexpected ways.

"When the Door Opened__,, one of the short stories included in Grand's collection Emotional Moments, is marked by fragmentariness, ambiguity, fluidity, and open-endedness. ${ }^{1}$ It begins with a reflective passage about the aesthetics of human affairs, wherein modernity is foregrounded through a series of tropes focused around crowds, transport, the bustle of urban life, and the idea of incompleteness. Grand's method here is suggestive of later Modernist vignettes by writers such as Virginia Woolf. Indeed, certain phrases and images in this opening paragraph seem to anticipate Woolf's famous statements in "Modern Fiction" $(1919) .^{2}$

What curious glimpses of life one catches sometimes unawares, scenes that flash forth distinctly from the tangled mass of movement, the crowded details, the inextricable confusion of human affairs as they appear to the looker-on in a great city. Seen amidst all the turmoil, from a hansom cab, from the top of an omnibus, from the platform of an underground station in a train that stops for a minute, from the pavement in a carriage blocked in the stream of traffic, by day and night, ... these intervals of intensity, the beginnings of episodes - 
tragic, heroic, amorous, abject; or the conclusion, which make the turning point the crisis of a life. If it be the beginning, how one aches to know what the end will be; and if it be the end, what would not one give for the first part! (Grand 217).

This sense of fiction as capturing mere "glimpses of life" is a decided break with the explicit coherence and confident cohesiveness of the Victorian realist novel. In its implicit acknowledgment of the necessarily incomplete nature of human experience as artistically rendered, Grand's opening positions her story squarely within an emerging Modernist sensibility. Yet it is also cognate with certain experimental writing of the late 1890s and early years of the twentieth century, for example, with the Literary Impressionism of Ford Madox Ford's The Soul of London (1905), which similarly emphasises the resistance of the movement and flux of the modern city to being captured in fiction:. "One sees, too, so many little bits of un-completed life"; "the constant succession of much smaller happenings ... that one never sees completed, [which] gives to looking out of train windows a touch of pathos and of dissatisfaction" (Ford 60; 61).

Grand's story, as alluded to in both her opening paragraph and echoed in Ford's text, problematizes the issue of endings by resisting closure and leaving the reader with an ambiguous and unexplained conclusion. Following the reflections discussed above, the narrator enters into conversation with an unnamed man who is sharing the carriage. After passing comment on an unhappily married couple who have just vacated the train, the man proceeds to reveal his own domestic situation. What is initially established as a progressive marriage, founded on the husband's trust and respect of his wife, gradually gives way to an exposure of the man's underlying insecurities when faced with circumstances that appear to demonstrate woman's essential duplicity and wantonness. After following his wife to a 
masked ball, the man mistakes her for a flirtatious woman of dubious morals who happens to be wearing the same costume. With a view to testing his supposed wife's fidelity, he takes the woman home. At the moment of discovery and realisation of his own compromised position, the husband hears his wife's latchkey in the door. At this climactic point, the man leaves the train, dooming the narrator to "be tormented with conjectures as to what happened when that door opened." (Grand 224)

Grand explores the subject of evolving gender relations at the fin de siècle through an emphasis on keys and doors. Doors are liminal spaces, between the public world and the private, the personal and the political spheres. Therefore, the latchkey becomes a potent symbol of women's increasing fluidity and movement between these realms. In drawing on this trope, Grand locates her story within wider themes of fin de siècle fiction. The latchkey became an iconic symbol for the New Woman, in fiction and drama. For instance, the character Victoria, in Sydney Grundy's satirical play, The New Woman (1894), speaks the line: “A woman has just as much right to a latchkey as a man.” Similarly, George Egerton’s Keynotes (1893), part of the publisher John Lane's “Keynotes” series, was significantly illustrated by Aubrey Beardsley with initial keys in black and white.

The wife's freedom becomes the central focus of the story, signalled by her ability to inhabit the public world on her own terms and her authority within the domestic space through possession of her own front-door key. Yet the husband's mistake, and the suspicion and anxiety this provokes, also acknowledges the precarious nature of female autonomy in this period. It is therefore appropriate that the story ends on a liminal and uncertain point, with the wife suspended in the doorway, literally between two worlds: "Her hand was already on the handle of the door" (Grand 224). Just as the narrator is prevented from knowing the outcome of this domestic history, so too were Grand's original readers uncertain as to the future of female autonomy and independence. 
Grand deliberately leaves the gender of the narrator unspecified, so that the reader is unaware as to whether the conversation on the train takes place between two men, or a man and a woman. This ambiguity has significance for the reader's interpretation. Is this a conversation between two men or is it, more interestingly, a frank exchange between a male and female who are strangers to one another? If we construe the narrator as female, this relates to the explicit and implicit themes of the text - that is, changing relations between the genders and women's independence in the public sphere. The emphasis on observation of the modern city also evokes the figure of the flâneur, and presents Grand's narrator, if read as female, as a kind of flâneuse, in the tradition of other urban New Woman writings, such as Amy Levy's poem, "Ballade of an Omnibus" (1889).

"When the Door Opened__ "supports arguments in recent scholarship that have offered a challenge to earlier paradigms of "rupture" between "Victorian" and "Modernist" writing, rethinking the boundaries of periodicity to suggest more nuanced theories based on continuities and connections. ${ }^{3}$ As Celia Marshik has suggested, “[b]y linking nineteenth- and twentieth-century artists in a historical trajectory of aesthetic change ... or by effacing the historical through a 'web' of Victorian Modernism ... it becomes possible to see new relations among authors previously separated by critical practice" (Marshik 14). While latenineteenth century figures such as George Egerton and Oscar Wilde have been recognised as experimental and avant-garde writers, who anticipate many of the dominant features of twentieth-century Modernism, Grand has remained, for the most part, outside of these debates. Yet, as Jennifer Nicol has recently argued, many of Grand's short stories demonstrate "a self-conscious and highly experimental blend of realism, impressionism and symbolism-[which] anticipates the twentieth-century modernist vignette" (Nicol 111). Wider investigation of the experimentalism of her short fiction would certainly suggest that Grand has a key place in current critical discussions. 
Notes

1. "When the Door Opened__ "was first published in the Idler, vol.6 (Jan 1898) pp.707-14., then collected in Sarah Grand, Emotional Moments. Hurst and Blackett, 1904.

2. I am thinking of the famous passage in Woolf's 'Modern Fiction', which begins:

"Examine for a moment an ordinary mind on an ordinary day." Virginia Woolf. The Common Reader, Vol.1., ed. Andrew McNeillie. Vintage, 2003, p.149.

3. See eg. recent works by Feldman, Pease, and Gillard-Estrada and Besnault-Levita, who have posited a more relational approach.

\section{Works Cited}

Feldman, Jessica R. Victorian Modernism: Pragmatism and the Varieties of Aesthetic Experience. Cambridge: Cambridge UP, 2002.

Gillard-Estrada, Anne-Florence and Anne Besnault-Levita. Beyond the Victorian / Modernist Divide: Remapping the Turn-of-the-Century Break in Literature, Culture and the Visual Arts. New York and Abingdon: Routledge, 2018.

Grand, Sarah. "When the Door Opened__,, in Angelique Richardson, ed., Women Who Did: Stories by Men and Women, 1890 - 1914. London: Penguin, 2005.

Hueffer, Ford Madox [later Ford Madox Ford]. The Soul of London: A Survey of a Modern City. London: Alston Rivers, 1905.

Marshik, Celia. British Modernism and Censorship. Cambridge: Cambridge UP, 2009.

Nicol, J. "Escape Artists: Adventure and Isolation in Women's Writing at the fin de siècle." PhD Thesis. Loughborough University, 2017. https://dspace.lboro.ac.uk/dspacejspui/handle/2134/25494

Pease, Allison, Modernism, Mass Culture, and the Aesthetics of Obscenity. New York: Cambridge UP, 2000. 